\title{
Chronic Olanzapine Treatment Causes Differential Expression of Genes in Frontal Cortex of Rats as Revealed by DNA Microarray Technique
}

\author{
S Hossein Fatemi*,', Teri J Reutiman', Timothy D Folsom', Christopher Bell', Lisa Nos', Peter Fried', \\ David A Pearce ${ }^{2}$, Sushmita Singh ${ }^{3}$, David P Siderovski ${ }^{4}$, Francis S Willard ${ }^{4}$ and Mitsunori Fukuda ${ }^{5}$ \\ 'Department of Psychiatry, Division of Neuroscience Research, University of Minnesota Medical School, Minneapolis, MN, USA; ' ${ }^{2}$ epartment of \\ Biochemistry and Biophysics, Center for Functional Genomics, University of Rochester School of Medicine, Rochester, NY, USA; ${ }^{3}$ Biomedical \\ Genomics Center, University of Minnesota, Minneapolis, MN, USA; ${ }^{4}$ Department of Pharmacology, University of North Carolina at Chapel Hill, \\ Chapel Hill, NC, USA; ${ }^{5}$ Fukuda Initiative Research Unit, RIKEN, Wako, Saitama, Japan
}

\begin{abstract}
Recent emerging biochemical data indicate that several important neuroregulatory genes and proteins may be involved in the etiology of schizophrenia and bipolar disorder. Additionally, the same genes appear to be targets of several psychotropic medications that are used to treat these disorders. Recent DNA microarray studies show that genes involved in synaptic neurotransmission, signal transduction, and glutamate/GABA regulation may be differentially regulated in brains of subjects with schizophrenia. We hypothesized that chronic administration of olanzapine to rats would alter expression of various genes that may be involved in the etiology of schizophrenia and mood disorders. Rats were administered olanzapine $(N=20,2 \mathrm{mg} / \mathrm{kg} / \mathrm{day})$ or sterile saline intraperitoneally $(N=20)$ daily for $2 \mathrm{l}$ days. Control and olanzapine-treated frontal cortices were analyzed using cDNA microarray technology. The results showed significant downregulation of 31 genes and upregulation of 38 genes by greater than two-fold in the drug-treated brains vs controls. Our results provide evidence for altered regulation of genes involved with signal transduction and cell communication, metabolism and energy pathways, transport, immune response, nucleic acid metabolism, and neuronal growth factors. Real-time quantitative RT-PCR analysis verified the direction and magnitude of change in six genes of interest: calbindin 3, homer I, regulator of G-protein signaling (RGS) 2, pyruvate kinase, Reelin and insulin 2. Western blotting showed significant upregulation in protein products for Reelin 410 and Reelin $180 \mathrm{kDa}$ and downregulation for NMDA3B and RGS2. Our results show for the first time that olanzapine causes changes in levels of several important genes that may be involved in the etiology and treatment of schizophrenia and other psychiatric disorders. Neuropsychopharmacology (2006) 3 I, I 888- 1899. doi: I 0.1038/sj.npp. I 30 I002; published online I I January 2006
\end{abstract}

Keywords: olanzapine; DNA microarray; schizophrenia; bipolar disorder; Reelin; insulin

\section{INTRODUCTION}

Olanzapine is a second-generation antipsychotic agent that, like clozapine, exhibits greater 5HT2A than D2 antagonism (Fatemi and Meltzer, 2000), but does not share clozapine's propensity for agranulocytosis. Olanzapine, similar to clozapine, has high affinity for a number of other receptors, that is, 5HT2A, 5HT2C, 5HT1A, 5HT6, 5HT7, 5HT3, muscarinic, $\alpha 1$-adrenergic, and histamine-H1 receptors (Fatemi and Meltzer, 2000; Bymaster et al, 1997). Additionally, olanzapine facilitates NMDA neurotransmission via effects on glutamatergic NMDA and AMPA receptors

*Correspondence: Dr SH Fatemi, Department of Psychiatry, Division of Neuroscience Research, University of Minnesota Medical School, MMC 392, 420 Delaware Street SE, Minneapolis, MN 55455, USA, Tel: + | 612626 3633, Fax: + | 612624 8935, E-mail: fatem002@umn.edu Received 16 May 2005; revised 17 October 2005; accepted 24 October 2005

Online publication: 2 November 2005 at http://www.acnp.org/citations/ Npp I I0205050324/default.pdf
(Tarazi et al, 2003; Wang et al, 2000). However, apart from its receptor-binding profile, little is known about the molecular mechanism of olanzapine drug action. Olanzapine has been used successfully to treat schizophrenia, bipolar disorder, and some forms of depression and anxiety. It has been hypothesized that antipsychotic agents affect various brain genes leading to changes in synaptic structure and function that may underlie clinical response (Chen and Chen, 2005).

Previous similar microarray studies investigating the effects of chronic administration of antipsychotics in brains of rodents are limited and yet informative (Chen and Chen, 2005; Chong et al, 2002; Kontkanen et al, 2002; MacDonald et al, 2005; Thomas et al, 2003). Chong et al (2004) showed that chronic administration of clozapine in rats for 28 days upregulated mRNA and protein for rat glia-derived nexin in brains of exposed animals. The authors suggest a possible neuroprotective role for nexin, a protease inhibitor, in clozapine treatment, most likely in the prevention of neuronal proteolytic degradation (Chong et al, 2004). In a 
different microarray-based study, Chong et al (2002) administered haloperidol in rats for 28 days and discovered that it upregulated both mRNA and protein for synapsin II gene by $>50 \%$ in the striatum of exposed rats. Recent studies have also shown involvement of synapsin in schizophrenic pathology (Mirnics et al, 2000). In a different study, Thomas et al (2003) used total gene expression analysis to examine gene expression profiles of mouse striatum and frontal cortex following exposure to 14 days of haloperidol or clozapine. The authors showed that both drugs increased genes associated with lipid metabolism, such as apolipoprotein D, the mouse homolog of oxysterol-binding protein-like protein 8, and lysophosphatidic acid acyltransferase (Thomas et al, 2003). MacDonald et al (2005) investigated gene profiles in the frontal cortex and striatum of rats in response to chronic exposure to haloperidol and clozapine. Several genes coding for presynaptic proteins including VAMP1, syntaxin $1 \mathrm{~A}$, and SNAP 25 were upregulated in the frontal cortex, potentially increasing synaptic plasticity and synaptic activity (MacDonald et al, 2005). Finally, in the most recent publication, Chen and Chen (2005) analyzed gene expression profiles in the frontal cortex of rats administered risperidone for 1-4 weeks. Several genes were upregulated in rat frontal cortex including three genes encoding catabolic enzymes of biogenic amine neurotransmitters, which may partly account for risperidone's clinical efficacy (Chen and Chen, 2005). Taken together, these studies indicate that multiple metabolic pathways are affected by the actions of antipsychotic medications, which affect gene families dealing with synaptic plasticity, neuroprotection, presynaptic neurotransmission, and lipid metabolism.

In the absence of DNA-microarray-based studies of the effects of olanzapine, we used microarray technology to investigate brain response to olanzapine following chronic treatment in rats and to identify potential genes of interest involved in the etiology of schizophrenia and bipolar disorder.

\section{MATERIALS AND METHODS}

\section{Animals and Drug Treatment}

Male Sprague-Dawley albino rats (Charles River) initially weighing approximately $250 \mathrm{~g}$ were housed in a temperature and humidity-controlled environment with a 12-h light/ dark cycle and had access to food and water ad libitum. The University of Minnesota Animal Care Committee approved all experimental procedures. Rats were randomly assigned to one of two groups: (1) olanzapine $(2 \mathrm{mg} / \mathrm{kg} / \mathrm{day}$, intraperitoneally (i.p.), $N=20$ ); or (2) sterile saline $(N=20)$, and administered drug or diluent in $1 \mathrm{ml}$ volume for 21 days. The dosage for olanzapine was chosen based on values obtained from the literature that correspond to clinically relevant human-equivalent dosage (Kusumi et al, 2000; Timmerman et al, 1999). Kusumi et al (2000) injected olanzapine at 1 or $2 \mathrm{mg} / \mathrm{kg}$, i.p., into rats for 3 weeks and showed no increase in D2 receptor density in the striatum. There is also published evidence that olanzapine at $4 \mathrm{mg} / \mathrm{kg}$ causes catalepsy (Hoffman and Donovan, 1995). Thus, our choice of $2 \mathrm{mg} / \mathrm{kg}$ dose was based on data that showed this dose to be sufficient enough to produce human-equivalent clinical efficacy but did not cause extrapyramidal side effects in rats. Animals were killed $24 \mathrm{~h}$ after the last injection under deep anesthesia using ketamine $(90 \mathrm{mg} / \mathrm{kg})$ and Nembutal $(40 \mathrm{mg} / \mathrm{kg})$. Brains were removed and the frontal cortex ( $N=4$ /group) was dissected and flash frozen in liquid nitrogen and stored at $-80^{\circ} \mathrm{C}$ for future assays.

\section{DNA Microarray}

Frontal cortical tissues were homogenized by standard procedures in Trizol (Gibco-BRL) for total mRNA extraction. Total RNA $(10 \mu \mathrm{g})$ from each sample was used to generate a high fidelity CDNA, which was modified at the $3^{\prime}$ end to contain an initiation site for T7 RNA polymerase as per the manufacturer's protocol (SuperChoice, Gibco-BRL). Upon completion of cDNA synthesis, $1 \mu \mathrm{g}$ of product was used in an in vitro transcription (IVT) reaction that contained biotinylated UTP and CTP, which was utilized for detection following hybridization to the microarray as per the manufacturer's protocol (ENZO). Full-length IVT product $(20 \mu \mathrm{g})$ was subsequently fragmented in $200 \mathrm{mM}$

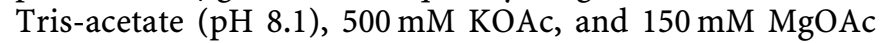
at $94{ }^{\circ} \mathrm{C}$ for $35 \mathrm{~min}$. Following fragmentation, all components generated throughout the processing procedure (cDNA, full-length cRNA, and fragmented cRNA) were analyzed by gel electrophoresis to assess the appropriate size distribution prior to microarray analysis. All samples generated were subject to gene expression analysis by the Affymetrix rat genome 2302.0 array set, which contained sequences from approximately 28000 known rat genes and ESTs at the University of Rochester Microarray Core Facility. Each gene on the array was represented by 16-20 pairs of $25 \mathrm{mer}$ oligonucleotides that spanned the coding region for each gene represented. Each probe pair consisted of a perfect match sequence that was complementary to the cRNA target and a miss match sequence that had a single base pair mutation in a region critical for target hybridization; this sequence served as a control for nonspecific hybridization. Hybridization, staining, and washing of all arrays were performed in the Affymetrix fluidics module as per the manufacturer's protocol. Streptavidin phycoerythrin stain (SAPE, Molecular Probes) was the fluorescent conjugate used to detect hybridized target sequences. The detection and quantitation of target hybridization was performed with a GeneArray Scanner (Hewlett Packard/ Affymetrix) set to scan each array twice at a factory set PMT level and resolution. In addition, all arrays were scanned pre- and post-antibody amplification to address potential issues with respect to the dynamic range of the scanner. All arrays referred to in this study were assessed for 'array performance' prior to data analysis. This process involves the statistical analysis of control transcripts that are spiked into the hybridization cocktail to assess array performance. In addition, several genes have been identified on each array to help assess the overall quality of signal intensity from all arrays. The result of this analysis has demonstrated that each array is within a 0.2 -fold difference of each other at baseline. This analysis affords the necessary confidence needed to apply a global scaling approach to data normalization in the subsequent analyses. 


\section{RNA Extraction and cDNA Synthesis}

Total RNA was extracted from brain tissues using a combination of Trizol for organic extraction followed by the RNAeasy total RNA extraction kit with modifications made by the URMC FGC (detailed protocol at http:// fgc.urmc.rochester.edu/). RNA quality was assessed by electrophoresis using the Agilent Bioanalyzer 2100 and spectrophotometric analysis prior to cDNA synthesis. Between 1 and $10 \mu \mathrm{g}$ of total RNA from each sample was used to generate a high fidelity cDNA using either oligo $\mathrm{dT}_{(12-18)}$ primers or random hexamers for reverse transcriptase primer. Superscript II was used for the reverse transcriptase and the manufacturer's protocol was used for the same procedure.

\section{Validation of Microarray by Real-Time Quantitative RT-PCR}

Gene expression was examined using TaqMan chemistry with probes and primers selected by the Applied Biosystems Assay on Demand Program. The following dye combinations were used for detection and data normalization: FAM (for the genes of interest), HEX (for normalizer genes, see below), BHQ1 (non-fluorescent quencher) and ROX (reference). Following probe and primer optimization, all cDNAs were diluted and used in a $10 \mu \mathrm{l}$ PCR reaction containing $5 \mu \mathrm{l}$ of ABI $2 \times$ Universal Master Mix, $1 \times$ of AOD, and RNAase/DNAase free water. The expression analysis of transcripts was carried out with predesigned and optimized TaqMan Gene Expression Assays with B2m ( $\beta-2$ microglobulin) or GADPH used as an endogenous control. All reactions were performed in triplicate and the experiments replicated three times. All reactions were run in an ABI 7900 with the following cycle parameters: 1 cycle of $50^{\circ} \mathrm{C}(2 \mathrm{~min})$, followed by $95^{\circ} \mathrm{C}(10 \mathrm{~min}), 40$ cycles of $95^{\circ} \mathrm{C}$ $(15 \mathrm{~s})$, followed by $60^{\circ} \mathrm{C}(1 \mathrm{~min})$. Data were collected at every temperature phase during each cycle. Raw data were analyzed using the Sequence Detection Software (ABI, Foster City, CA) while relative quantitation using the comparative threshold cycle $\left(C_{\mathrm{T}}\right.$ method) was performed in Microsoft Excel (ABI Technote\#2: Relative Gene Expression Quantitation). All genes presented were analyzed as described above.

\section{Data Analysis}

Multiple data analysis approaches were used to identify interesting genes within this experimentally tractable approach to studying the effects of psychotropic agents on neuronal tissue. The Microarray Analysis Suite 5.0 (Affymetrix) was employed to generate one approach to comparative analysis presented in this study. Distinct algorithms were used to determine the detection signal, which distinguished the presence or absence of a transcript, the differential change in gene expression (increase (I), decrease (D), marginal increase (MI), marginal decrease (MD), and no change (NC)), and the magnitude of change, which is represented as fold change. The fold change of any transcript between the baseline and experimental is calculated following global scaling. All data represented from this first approach were from pairwise comparison analysis. The second approach to identifying differentially expressed genes utilized GeneSpring (Silicon Genetics).

Following each normalization approach, all genes differentially expressed were clustered based on biological relevance. Genes were assessed based on primary biological function and grouped accordingly. All data have been organized in a central database in the University of Rochester Functional Genomics Center and are accessible through a variety of web-based solutions (http://fgc. urmc.rochester.edu/data2.html). Additional information on normalization methods can be found on the Neuropsychopharamacology website published as a supplement to this manuscript.

\section{SDS-PAGE and Western Blotting}

Brain tissue $(\sim 25 \mathrm{mg})$ per rat was cut and placed on ice in lysis buffer ( $3 \mathrm{ml} / \mathrm{g}$ of tissue) (20 mM Tris, $\mathrm{pH} 8.0,0.2 \mathrm{mM}$ EDTA, $150 \mathrm{mM} \mathrm{NaCl}, 3 \%$ Igepal/NP40 (v/v), 1\% sodium deoxycholate $(\mathrm{w} / \mathrm{v}), 0.1 \%$ SDS (w/v), $50 \mu \mathrm{g} / \mathrm{ml}$ leupeptin, $0.2 \mathrm{mM}$ PMSF, $1 \mathrm{mM}$ sodium orthovanadate, and $30 \mu \mathrm{l} / \mathrm{ml}$ buffer Aprotinin (Sigma A6279)). Tissue samples were homogenized using a Kontes hand pestle while the temperature was maintained at $4{ }^{\circ} \mathrm{C}$. Following homogenization, an additional $1 \mu \mathrm{l}$ of PMSF $(0.2 \mathrm{mM})$ was added to each sample, and the samples were set on ice for $30 \mathrm{~min}$. The homogenates were centrifuged for $20 \mathrm{~min}$ at $10000 \mathrm{~g}$ at $4{ }^{\circ} \mathrm{C}$. Supernatants were collected and assayed for total protein using the Bradford method (BioRad). Samples were stored at $-86^{\circ} \mathrm{C}$ until used.

Samples were mixed with denaturing SDS sample buffer (20\% glycerol, $100 \mathrm{mM}$ Tris, $\mathrm{pH} 6.8,0.05 \% \mathrm{w} / \mathrm{v}$ bromophenol blue, $2.5 \%$ SDS (w/v), $5 \% \beta$-mercaptoethanol) and denatured by heating at $100^{\circ} \mathrm{C}$ for $5 \mathrm{~min}$. For $\beta$-actin and synaptotagmin IV, $10 \%$ SDS-polyacrylamide gels were prepared with standard Laemmli solutions (BioRad). In all, $60 \mu \mathrm{g}$ of protein per lane was loaded onto the gel and electrophoresed, initially for $15 \mathrm{~min}$ at $75 \mathrm{~V}$ and then for $50 \mathrm{~min}$ at $150 \mathrm{~V}$ at room temperature (RT). The proteins were electroblotted onto nitrocellulose paper for $2 \mathrm{~h}$ at $300 \mathrm{~mA}$ at $4^{\circ} \mathrm{C}$. Protein blots were blocked overnight at $4^{\circ} \mathrm{C}$ with $0.2 \%$ I-Block (Tropix) in PBS with $0.3 \%$ Tween-20. The blots were then incubated with primary antibody for $1 \mathrm{~h}$ at RT (mouse anti- $\beta$-actin, Sigma A5441, 1:5000; or rabbit anti-synaptotagmin IV, a gift from Dr Fukuda, 1:1000) followed by secondary antibody incubation for $1 \mathrm{~h}$ at RT (goat anti-mouse or goat anti-rabbit IgG, HRP conjugated, 1:80000, both from Sigma). Between each step, the immunoblots were rinsed with PBS-T. The immune complexes were visualized using the ECL Plus detection system (Amersham Pharmacia Biotech) and exposed to CLXposure film (Pierce). Sample densities were analyzed using a Bio-Rad densitometer and Quantity One software.

NMDA3B was analyzed as above, with the following changes: an $8 \%$ SDS-polyacrylamide gel was used; after transfer, the blot was blocked at RT for $1 \mathrm{~h}$, followed by overnight incubation with primary antibody (rabbit anti-NMDA3B, Upstate $07-351,1: 1000$ ) at $4^{\circ} \mathrm{C}$. Secondary antibody was (goat-anti-rabbit IgG, HRP conjugated, 1:80000) applied for $1 \mathrm{~h}$ at $\mathrm{RT}$, and all washes and visualization took place as described above. 
Reelin was analyzed as above (Fatemi et al, 2005a, b), with the following changes: $6 \%$ SDS-polyacrylamide gel was used; gels were run at $75 \mathrm{~V}$ for $15 \mathrm{~min}$ at RT, as above, but then run at $150 \mathrm{~V}$ for $60 \mathrm{~min}$. Gels were transferred to PVDF membrane (prewet in methanol for $1 \mathrm{~min}$, rinsed in $\mathrm{dH}_{2} \mathrm{O}$, and soaked in transfer buffer for at least $20 \mathrm{~min}$ prior to assembling transfer sandwich) at $150 \mathrm{~mA}$ for $15 \mathrm{~h}$ at $4{ }^{\circ} \mathrm{C}$. Blots were blocked for $6 \mathrm{~h}$ at RT and primary antibody (mouse anti-Reelin, Chemicon MAB5366, 1:1000) was applied for $22 \mathrm{~h}$ at $4{ }^{\circ} \mathrm{C}$, and secondary antibody (goat anti-mouse IgG, HRP conjugated, Sigma, 1:1000) was applied for $1 \mathrm{~h}$ at RT. All washes and visualization took place as described above.

Regulator of G-protein signaling (RGS) 2 utilized a Tricine SDS-PAGE technique, a modified version of that has been described by Schägger and von Jagow (1987). Briefly, $16 \%$ SDS-polyacrylamide gels were prepared and $60 \mu \mathrm{g}$ of protein was loaded onto the gel in $2 \times$ loading buffer (Invitrogen) and electrophoresed (1 M tricine, $1 \mathrm{M}$ TRIS base, $0.1 \%$ SDS) at $30 \mathrm{~V}$ for $40 \mathrm{~min}$, then at $110 \mathrm{~V}$ for $110 \mathrm{~min}$, both at RT. Gels were transferred onto $0.22 \mu \mathrm{m}$ PVDF-Plus (Osmonics, Inc., GE Healthcare) membrane (prewet as above) at $300 \mathrm{~mA}$ for $120 \mathrm{~min}$ at $4{ }^{\circ} \mathrm{C}$. The blot was then rinsed in $\mathrm{dH}_{2} \mathrm{O}$ and blocked for $1 \mathrm{~h}$ at $\mathrm{RT}$ and incubated in primary antibody (rabbit anti-RGS2, a gift from Dr Siderovski, 1:1000) overnight at $4^{\circ} \mathrm{C}$. Following rinses in PBS-T, secondary antibody (goat anti-rabbit IgG, HRP conjugated, Sigma, 1:80 000) was applied for $1 \mathrm{~h}$ at RT, and all washes and visualization took place as described above.

The densities of approximately 410,330 , and $180 \mathrm{kDa}$ (Reelin), $97 \mathrm{kDa}$ (NMDA3B), 50 and $25 \mathrm{kDa}$ (RGS2), $48 \mathrm{kDa}$ (synaptotagmin IV), and $46 \mathrm{kDa}(\beta$-actin), immunoreactive bands were quantified with background subtraction. Control samples $(30-90 \mu \mathrm{g})$ were immunoblotted to ascertain that all samples fell within the linear range of the densitometric curve (not shown). Results obtained are based on between two and eight independent experiments with $n=3$ or $n=4$ rats per gel. For each experiment, control and olanzapine samples were run on the same gel and processed simultaneously to avoid variability due to intragel differences.

\section{Statistical Analysis}

For microarray data, all statistical analyses were performed using SPSS. Differences of the normalized mRNA expression levels of selected genes between drug-treated and saline-treated rats were assayed using Student's $t$-test. Significant differences are defined as those with a $P$-value $<0.05$

For Western blots, differences of the protein levels of selected genes between drug-treated and saline-treated rats were normalized against $\beta$-actin and assayed using a Student's $t$-test. Significant differences are defined as those with a $P$-value $<0.05$.

\section{RESULTS}

Olanzapine treatment of rats for 21 days resulted in significant $(P<0.05)$ downregulation of 31 genes and significant $(P<0.05)$ upregulation of 38 genes in the frontal cortex of drug-treated rats (Table 1). We used multiple types of data analytic approaches (RMA, GCRMA, and MAS5) for the current microarray studies because different approaches analyze data in fundamentally different ways, allowing for increased data mining (Fatemi et al, 2005c; Irizarry et al, 2003; Wu et al, 2004; Hubbell et al, 2002). For this data set, RMA, GCRMA, and MAS5 analyses were combined to provide an optimal number of statistically significant changes in gene expression. Data presented represent all genes with altered expression at significant levels. Additionally, the genes were compiled on the basis of statistical significance using standard $t$-test and at gene expression levels of 2 -fold or more $v s$ saline-treated rat brains following previous methodology (Elshatory et al, 2003; Fatemi et al, 2005c).

Of note, examples of some of the upregulated genes of interest included homer 1, sarcosin, timeless, calgranulin A and $B$, cocaine and amphetamine-regulated transcript (CART), ileal peptidase, $\gamma$-synuclein and calpain 8 (Table 1). Examples of some of the downregulated genes included calbindin 3, prolactin-like protein A, RGS2, fibroblast growth factor receptor 2, insulin-like growth factor binding protein 2 (IGFBP2), sucrase-isomaltase, methionine synthase, and NMDA3B (Table 1). Finally, real-time quantitative RT-PCR (QPCR) verified magnitude and direction of change in several significantly affected genes of interest, including calbindin 3, homer 1, pyruvate kinase (liver and RBC), RGS2, and insulin 2 (Table 2).

Tabulation of the significantly affected genes, based on functional relevance (Table 3 ), showed involvement of genes from multiple biological pathways, such as signal transduction/cell communication, transport, protein metabolism, and cell growth/maintenance, in the olanzapine mechanism of drug response (Table 3 ).

We also measured protein levels for Reelin, NMDA receptor 3B, synaptotagmin IV, and RGS2 using Western blotting. Reelin molecules appeared on SDS-PAGE as multimeric bands ranging from $\approx 410$ to $\approx 330$ to $\approx 180 \mathrm{kDa}$ (Figure 1a) and showed significant upregulation in the 410 and $180 \mathrm{kDa}$ isoforms normalized against $\beta$-actin in olanzapine-treated rat frontal cortex $(P=0.0033$ and 0.0001 , respectively; Figure $1 \mathrm{~b}$ and d; Table 4$)$. The $330 \mathrm{kDa}$ isoform of Reelin showed a nonsignificant upregulation (Figure 1c; Table 4). NMDA3B appeared as a single band at $\approx 97 \mathrm{kDa}$ and showed significant downregulation in olanzapine-treated rat frontal cortex $(P=0.018$; Table 4). The RGS2 antibody recognized RGS2 as a dimer band at $\approx 50 \mathrm{kDa}$ and a monomer band at $\approx 25 \mathrm{kDa}$ (F.S. Willard and D.P. Siderovski, unpublished observations). The RGS2 dimer band showed a significant downregulation in olanzapine-treated rat frontal cortex $(P=0.0061$; Table 4$)$, as did the total RGS2 protein (dimer and monomer bands taken together; $P=0.0039$ ), while the $25 \mathrm{kDa}$ monomer band showed a nonsignificant downregulation (Table 4). Synaptotagmin IV appears as a single band at $\approx 48 \mathrm{kDa}$ and showed a nonsignificant downregulation in olanzapine-treated rat frontal cortex (Table 4). There were no significant differences in levels of $\beta$-actin in olanzapine-treated brains $v s$ controls (Table 4) indicating absence of any major treatment-related effects on protein stability. 
Table I Effects of Chronic Administration of Olanzapine on Rat Frontal Cortex

\begin{tabular}{|c|c|}
\hline Upregulated genes & Downregulated genes \\
\hline Aldehyde oxidase $I^{\text {a }}$ & Activating transcription factor $3^{a}$ \\
\hline Angiopoietin-like $2^{b}$ & Calbindin $3^{b}$ \\
\hline Calpain $8^{\mathrm{b}}$ & Calcium-independent alpha-latrotoxin receptor homolog $3^{\mathrm{a}}$ \\
\hline Chemokine-binding protein $2^{\mathrm{b}}$ & Carbohydrate (chondroitin 6/keratan) sulfotransferase $3^{\mathrm{b}}$ \\
\hline Cold shock domain protein $A^{b}$ & Cytochrome P450, subfamily II $\mathrm{A}^{\mathrm{b}}$ \\
\hline Cysteinyl leukotriene receptor $\mathrm{I}^{\mathrm{a}}$ & D site albumin promoter binding protein ${ }^{\mathrm{a}}$ \\
\hline Endothelial and smooth muscle cell-derived neuropilin-like protein ${ }^{\mathrm{b}}$ & Dentin sialophosphoprotein $^{\mathrm{a}}$ \\
\hline Fibroblast growth factor $3^{\mathrm{b}}$ & Fibroblast growth factor receptor $2^{\mathrm{a}}$ \\
\hline Galanin receptor $\left.\right|^{b}$ & Glutamate receptor, ionotropic, NMDA3B ${ }^{\mathrm{a}}$ \\
\hline Insulin $2^{b}$ & Interleukin 2 receptor, beta chain ${ }^{\mathrm{a}}$ \\
\hline Mast cell protease $8^{b}$ & Interleukin 23 , alpha subunit $p 19^{a}$ \\
\hline MT-protocadherin ${ }^{a}$ & Lecithin-retinol acyltransferase $^{\mathrm{b}}$ \\
\hline Muscle glycogen phosphorylase ${ }^{b}$ & Methionine synthase ${ }^{\mathrm{a}}$ \\
\hline N-acetylated alpha-linked acidic dipeptidase-like I (ileal peptidase II 00) & Prolactin-like protein $A^{b}$ \\
\hline Pancreatic polypeptide receptor $\mathrm{I}^{\mathrm{b}}$ & $\begin{array}{l}\text { Protein phosphatase } 2 \text { (formerly 2A), regulatory subunit A (PR 65), alpha } \\
\text { isoform }^{\mathrm{a}}\end{array}$ \\
\hline Phospholipase A2, group IVA (cytosolic, calcium-dependent) ${ }^{\mathrm{a}}$ & Regulator of G-protein signaling protein $2(\mathrm{RGS} 2)^{\mathrm{b}}$ \\
\hline Procollagen, type I, alpha $2^{\mathrm{a}}$ & Solute carrier family 22, member $3^{\mathrm{a}}$ \\
\hline Pyruvate kinase, liver and $\mathrm{RBC}^{\mathrm{a}}$ & Solute carrier family 24, member $3^{a}$ \\
\hline Sodium channel, nonvoltage-gated, type I, alpha polypeptide ${ }^{b}$ & Zinc finger, $\mathrm{C} 3 \mathrm{HC} 4$ type (RING finger) ${ }^{\mathrm{a}}$ \\
\hline \multicolumn{2}{|l|}{ Solute carrier family 12, member $1^{b}$} \\
\hline \multicolumn{2}{|l|}{ Solute carrier family 38 , member $1^{b}$} \\
\hline \multicolumn{2}{|l|}{ Synuclein, gamma ${ }^{b}$} \\
\hline \multicolumn{2}{|l|}{ Thrombomodulin $^{\mathrm{a}}$} \\
\hline \multicolumn{2}{|l|}{ Timeless (Drosophila) homolog ${ }^{\mathrm{b}}$} \\
\hline \multicolumn{2}{|l|}{ Tissue-type vomeronasal neurons putative pheromone receptor $\mathrm{V} 2 \mathrm{R} 2^{\mathrm{b}}$} \\
\hline Transmembrane 4 superfamily member $3^{\mathrm{a}}$ & \\
\hline
\end{tabular}

All genes shown are significantly $(P<0.05)$ changed by greater than two-fold vs saline-treated controls.

a Fold change of at least 2.0.

${ }^{b}$ Fold change of at least 4.0.

\section{DISCUSSION}

Our studies are the first to demonstrate, at the molecular level, the chronic effects of olanzapine on multiple gene families of interest in the frontal cortex of the rat, spanning genes involved in signal transduction, cell communication, metabolism, energy pathways, transport, immune response, nucleic acid metabolism, and neuronal growth factors (Table 3). Additionally, scrutiny of the affected genes identified several genes/proteins implicated in the pathology of schizophrenia and mood disorders (Table 5).

\section{Genes Upregulated due to Olanzapine Treatment}

A total of 38 genes were upregulated significantly by olanzapine treatment. One of these upregulated genes is $C A R T$, which is involved in feeding, drug reward, and stress. 
Table 2 QPCR Results for Selected Genes Involved in Olanzapine Treatment

\begin{tabular}{llll}
\hline Protein & Gene ID & Fold change & Two-tailed $\boldsymbol{p}$-value \\
\hline Calbindin 3* & CALB3 & -1.46 & 0.0004 \\
Homer, neuronal immediate early gene, I & HOMERI & +1.08 & 0.5677 \\
Insulin 2* & INS2 & +3.68 & 0.0100 \\
Pyruvate kinase, liver and RBC & PKLR & +1.47 & 0.0601 \\
Reelin* & RELN & +1.65 & 0.0046 \\
Regulator of G-protein signaling protein 2* & RGS2 & -2.32 & 0.0002 \\
\hline
\end{tabular}

* Statistically significant $(P<0.05)$.

CART peptides are distributed in the brain, gut, pituitary, adrenals, and pancreas (Hunter and Kuhar, 2003). A previous report suggested an association between a polymorphism in intron 1 of CART gene and alcoholism (Jung et al, 2004). In homozygous circadian clock mutant mice, which have an attenuated diurnal feeding rhythm and which are hyperphagic and obese and develop a metabolic syndrome of hyperleptinemia, hyperlipidemia, hepatic steatosis, hyperglycemia, and hypoinsulinemia, CART expression is significantly reduced (Turek et al, 2005). $C A R T$, ghrelin, and orexin all contain clock responsive Ebox elements (Turek et al, 2005). Interestingly, CART, which also increases glucose and regulates body weight, is upregulated significantly by olanzapine (Tables 1, 3) potentially providing a mechanistic insight into increases in body weight observed in schizophrenic patients treated with this drug.

Fibroblast growth factors (FGF) are members of a family of trophic factors whose expression are regulated by neurotransmitters or learning (Ovalle et al, 2001). FGF has previously been shown to be increased in serum of schizophrenic patients (Hashimoto et al, 2003). Additionally, members of the FGF gene family have been known to be altered in depression (Evans et al, 2004). Olanzapine increased mRNA for FGF3 and decreased FGF receptor 2 in the frontal cortex of exposed rats, presumably facilitating signal transduction, cell communication, and neuronal growth (Tables 1,3). FGFs appear to be targets of several psychotropic medications including clozapine (Riva et al, 1999), E-5842 (Ovalle et al, 2001), and olanzapine. Riva et al (1999) showed increases in levels of FGF2 mRNA and protein in rat striatum following administration of clozapine. Ovalle et al (2001) showed that E-5842, a preferential sigma-1 receptor agonist and ligand and a putative atypical antipsychotic, causes upregulation of FGF2 mRNA in the prefrontal cortex (PFC) and striatum and downregulation of FGF2 mRNA in the hypothalamus of rat brains following 21-day chronic exposure. Thus, it appears that FGF2 could play a role as a neuroprotective agent, which is upregulated by olanzapine, clozapine, and sigma- 1 receptor ligand E5842 (Ovalle et al, 2001; Riva et al, 1999). Olanzapine is also capable of upregulating levels of nerve growth factor and downregulating levels of $B D N F$ in various areas of the rat brain (Angelucci et al, 2005) attesting to varied effects of olanzapine on different trophic factors in the brain.

Impairment of glycolytic pathways has been investigated in schizophrenia (Stone et al, 2004). Stone et al (2004) identified positive associations between schizophrenia and several enzymes involved in glycolysis, including 6-phosphofructo-2-kinase/fructose-2, 6-biphophatase 2, hexokinase 3 , and pyruvate kinase 3. Similarly, olanzapine treatment of rats caused significant alterations in several key glycolytic enzymes, such as increases in muscle glycogen phosphorylase and in $R B C$ and liver pyruvate kinase (which also showed a near significant increase based on our QPCR results; Table 2) and a decrease in sucrase-isomaltase (Tables 1, 3).

The Homer family of genes and proteins are scaffoldrelated molecules that are involved in the modulation of glutamate receptors and $\mathrm{Ca}^{2+}$ stores and affect signal transduction cascades (VanderVorst, 2004). The Homer protein family also assists in assembly of glutamate receptors and $\mathrm{Ca}^{2+}$ channels in the plasma membrane (VanderVorst, 2004). Norton et al (2003) identified one SNP (Homer 1 IVS $4+18 \mathrm{~A}>\mathrm{G}$ ) to be associated with schizophrenia, confirmed by genotyping. Govek et al (2004) also reported absence of a Homer interacting protein, namely oligophrenin-1 (a Rho-GTPase activating protein) in a family affected with X-linked mental retardation. Olanzapine in rats increased levels of Homer 1 significantly (Tables $1,3)$, a result that was confirmed through QPCR, albeit nonsignificantly (Table 2). Other studies have shown haloperidol increasing Homer in both the caudate putamen and nucleus accumbens of rats (Polese et al, 2002). Clozapine, however, increased Homer in the accumbens only (Polese et al, 2002). Thus, it appears that haloperidol, clozapine, and olanzapine all increase Homer mRNA levels in various brain sites of rodents modulating glutamate metabotropic system.

Olanzapine increased expression of insulin 2 significantly (Tables 1,3 ) in exposed rat frontal cortex. There are two insulin isomers in rat, namely insulin 1 and insulin 2, with the latter species being more responsive to changes in glucose levels (Toriumi and Imai, 2003). Insulin 2 is the probable analogue of human insulin in rat (Toriumi and Imai, 2003). The increase in insulin 2 gene expression was verified by QPCR, showing a significant increase $(p<0.01)$ in insulin 2 mRNA by $\approx 4$-fold in olanzapine-treated rats (Table 2). In contrast, IGFBP2 was reduced by olanzapine. Transgenic mice, which overexpress IGFBP1, display lateral ventricular enlargement (Doublier et al, 2000). In addition to effects on brain development, perturbations of insulin/ insulin-like growth factors have been associated with susceptibility to schizophrenia (Gunnell and Holly, 2004; DeLisi et al, 2002). Olanzapine-induced increases in levels of insulin 2 and decreases in level of IGFBP2 may reflect the 


\section{Chronic olanzapine treatment}

SH Fatemi et al

Table 3 Biochemical Pathways Involved in Olanzapine Action

\section{Biological function}

Signal transduction; cell communication

Metabolism; energy pathways

Transport

Immune response

Nucleic acid metabolism

Growth factors

Miscellaneous

\section{Genes upregulated by olanzapine}

Chondroitin sulfate proteoglycan 3

Cysteinyl leukotriene receptor I

Endothelial and smooth muscle cell-derived neuropilin-like protein

Galanin receptor I

Glutamate receptor interacting protein

Homer, neuronal immediate early gene, I

MT-protocadherin

Pancreatic polypeptide receptor I

Regulator of G-protein signaling protein 19 (RGS I9)

SI00 calcium-binding protein A8 (calgranulin A)

SI00 calcium-binding protein A9 (calgranulin B)

Transmembrane 4 superfamily member 3

Aldehyde oxidase 1

Calpain 8

Heme oxygenase I

Muscle glycogen phosphorylase

Phospholipase A2, group IVA (cytosolic, calcium-dependent) Lecithin-retinol acyltransferase

Pyruvate kinase, liver and RBC

Synuclein, gamma

Insulin 2

Apolipoprotein A-V

Sodium channel, nonvoltage-gated, type I, alpha polypeptide Solute carrier family 12, member I

Solute carrier family 38 , member I

Chemokine-binding protein 2

Rat mRNA for RTI.D beta chain similar to Class II MHC RTI.D(n) beta chain precursor

RTI class Ib gene, locus M3

Thrombomodulin

Cocaine and amphetamine regulated transcript (CART)

Cold shock domain protein A

Timeless (Drosophila) homolog

Angiopoietin-like 2

Fibroblast growth factor 3

Mast cell protease 8

$\mathrm{N}$-acetylated alpha-linked acidic dipeptidase-like I (ileal peptidase II00)

Procollagen, type I, alpha 2

Sarcomeric muscle protein (Sarcosin)

Tissue-type vomeronasal neurons putative pheromone receptor V2R2

\section{Genes downregulated by olanzapine}

Calcium-independent alpha-latrotoxin receptor homolog 3

Fibroblast growth factor receptor 2

Glycoprotein hormone alpha 2

Insulin-like growth factor binding protein 2

Protein phosphatase 2 , regulatory subunit $A$ (formerly $2 A$ ), regulatory subunit $A$ (PR 65), alpha isoform

Regulator of G-protein signaling protein 2 (RGS2)

Synaptotagmin 4

Thyroid stimulating hormone, receptor

Carbohydrate (chondroitin 6/keratan) sulfotransferase 3

Chymotrypsinogen B

Cytochrome P450IIB3

Cytochrome P450, subfamily IIA

Methionine synthase

Prolactin-like protein A

Sucrase-isomaltase

UDP glycosyltransferase 2 family, polypeptide B

Calbindin 3

Calcium activated potassium channel beta 4 subunit

Glutamate receptor, ionotropic, NMDA3B

Solute carrier family 22, member 3

Solute carrier family 24, member 3

Interleukin I receptor accessory protein

Interleukin 2 receptor, beta chain

Interleukin 23, alpha subunit p 19

Activating transcription factor 3

$\mathrm{D}$ site albumin promoter binding protein

Zinc finger, $\mathrm{C} 3 \mathrm{HC} 4$ type (RING finger)

Dentin sialophosphoprotein

Tripartite motif protein 17

Uncoupling protein UCP-4 
a
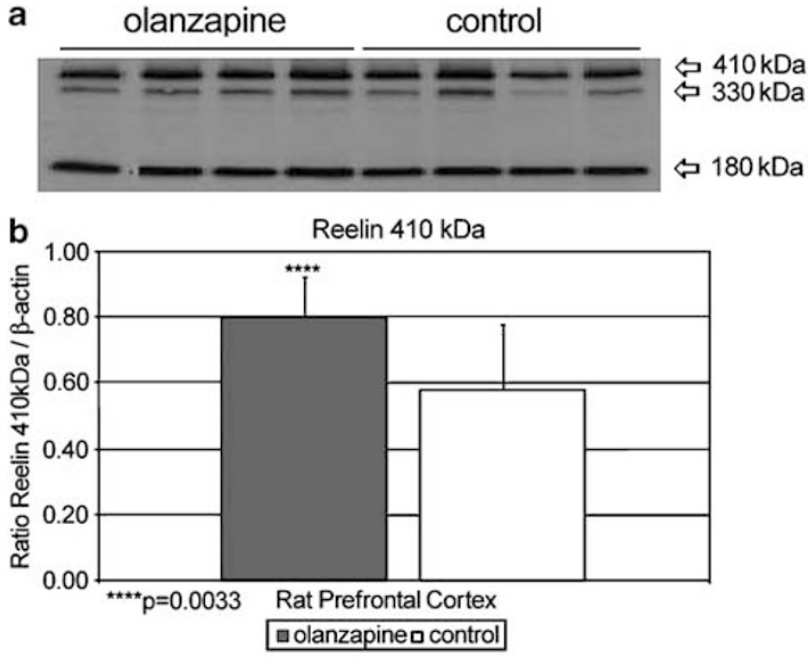

C Reelin $330 \mathrm{kDa}$
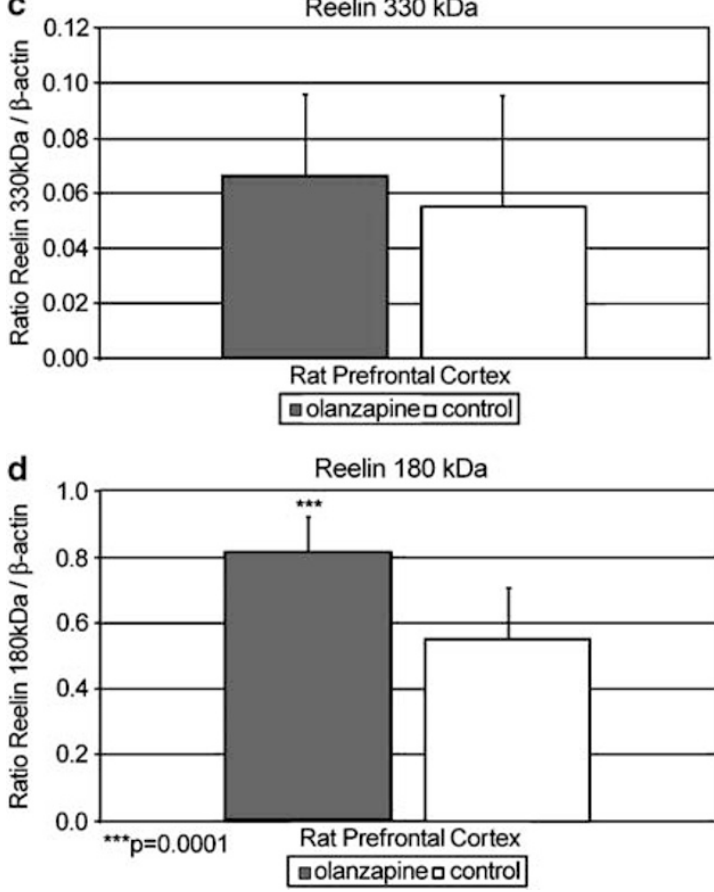

Figure I (a) Reelin bands of 410,330 , and $180 \mathrm{kDa}$ from the PFC homogenates (70 $\mu \mathrm{g}$ protein per lane) of representative olanzapine-treated and control rats are shown. Mean Reelin 410 (b), 330 (c), and I 80 (d) kDa/ $\beta$-actin ratios for olanzapine-treated (filled histogram bars) and control rats (unfilled histogram bars) are shown. Levels of Reelin $410 \mathrm{kDa} / \beta$-actin (b) and Reelin $180 \mathrm{kDa} / \beta$-actin (d) were significantly increased vs controls $(P=0.0033$ and $0.000 \mathrm{I}$, respectively). Reelin $330 \mathrm{kDa} / \beta$-actin (c) was nonsignificantly increased vs controls.

antiapoptotic action of olanzapine and its multifarious positive roles in neurogenesis, myelination, synaptogenesis, and dendritic branching (Gunnell and Holly, 2004).

Calgranulin B, a calcium binding protein that is found in a wide range of cells, has been shown to be involved in a number of cellular processes, such as cell cycle progression and differentiation. Levels of calgranulin $B$ blood cellderived RNA have recently been reported to be significantly increased in schizophrenic subjects (Tsuang et al, 2005). Interestingly, olanzapine significantly increased calgranulin $A$ and $B$ levels in rats treated with this agent.
Finally, while the DNA array only showed a trend for increase in Reln gene, its protein product, Reelin, was significantly upregulated in rat brain. Reelin glycoprotein has been implicated in pathology of schizophrenia, mood disorders, and autism (Fatemi et al, 2000, 2005c; Guidotti et al, 2000). Our lab has previously demonstrated decreased levels of Reelin in brains of patients with autism, bipolar disorder, major depression and schizophrenia (Fatemi et al, $2000,2001 \mathrm{a}, \mathrm{b}, 2002)$. We were therefore interested in examining the effect of olanzapine on Reelin levels. Our protein measurements in the frontal cortex showed a significant upregulation for Reelin 410 and $180 \mathrm{kDa}$ proteins in the drug-exposed rats (Figure $1 \mathrm{~b}$ and $\mathrm{d}$ ). By the same token, QPCR experiments showed significant upregulation in Reelin mRNA by olanzapine (Table 2). These increases in Reelin mRNA and protein product by olanzapine suggest a possible mechanism for olanzapine's efficacy in modulating synaptic plasticity.

\section{Genes Downregulated due to Olanzapine Treatment}

A total of 31 genes were downregulated significantly by olanzapine treatment. One of these genes was RGS2. RGS proteins enhance hydrolysis of GTP to GDP by G-protein $\alpha$-subunits, thereby reducing the $\alpha$-subunit activation of downstream effectors (Kehrl and Sinnarajah, 2002). RGS proteins are therefore known as GTPase activating proteins. $R G S 2$, first identified in a screen for activation genes in human lymphocytes (Siderovski et al, 1994), blocks Gq $\alpha$-mediated signaling and inhibits Gs signaling to certain adenylyl cyclases as well (Kehrl and Sinnarajah, 2002). RGS2 mRNA has been shown to have widespread expression in cerebral cortical layers, several thalamic and hypothalamic nuclei, and hindbrain regions (Grafstein-Dunn et al, 2001). Targeted mutations of RGS2 in mice increase anxiety levels and alter synaptic development in hippocampal CA1 neurons (Kehrl and Sinnarajah, 2002). Kehrl and Sinnarajah (2002) suggest that RGS2 could negatively regulate metabotropic glutamate receptors and thus affect long-term synaptic plasticity in the hippocampus. Levels of RGS4 are known to be decreased in both schizophrenia and Alzheimer's disease (Mirnics et al, 2001; Muma et al, 2003). Reductions in levels of RGS4 lead to increases in levels of RGS2 as a compensatory response (Taymans et al, 2003). Interestingly, olanzapine significantly decreased RGS2 gene expression (Tables 1,3). This decrease in RGS2 was verified by QPCR measurement (Table 2), showing a significant 2.32-fold decrease in RGS2 mRNA in exposed rat frontal cortex (Table 2). Additionally, olanzapine significantly decreased RGS2 protein product in rat frontal cortex $v s$ controls (Table 4).

The glutamatergic involvement in pathology of schizophrenia and bipolar disorder is well known. Glutamate receptor $N M D A 3 B$ is purported to be involved in schizophrenia (Lipsky and Goldman, 2003). Olanzapine significantly reduced glutamate ionotropic $N M D A 3 B$ receptor expression while increasing glutamate receptor interacting protein (GRIP) expression (Tables 1,3), suggesting an effect on glutamate transmission. QPCR experiments also showed a significant reduction in levels of $N M D A 3 B$ mRNA $(p<0.018)$ in drug-treated rat frontal cortex (Table 4). 
Table 4 Western Blotting Results for Selected Proteins Involved in Olanzapine Treatment

\begin{tabular}{|c|c|c|c|c|}
\hline Protein & Olanzapine-treated (mean \pm SD) & Control (mean \pm SD) & $\%$ change & $P$-value ${ }^{\text {a }}$ \\
\hline Reelin $410 \mathrm{kDa} / \beta$-actin & $0.799 \pm 0.118$ & $0.577 \pm 0.202$ & $38 \% \uparrow$ & 0.0033 \\
\hline Reelin $330 \mathrm{kDa} / \beta$-actin & $0.066 \pm 0.033$ & $0.056 \pm 0.041$ & $18 \% \uparrow$ & NS \\
\hline Reelin $180 \mathrm{kDa} / \beta$-actin & $0.811 \pm 0.112$ & $0.553 \pm 0.159$ & $47 \% \uparrow$ & 0.0001 \\
\hline NMDA $3 \beta / \beta$-actin & $0.154 \pm 0.047$ & $0.232 \pm 0.078$ & $34 \% \downarrow$ & 0.0180 \\
\hline RGS2 $50 \mathrm{kDa}$ Dimer $/ \beta$-actin & $0.356 \pm 0.163$ & $0.602 \pm 0.194$ & $41 \% \downarrow$ & 0.0061 \\
\hline Total RGS2/ $\beta$-actin & $0.37 I \pm 0.154$ & $0.625 \pm 0.189$ & $41 \% \downarrow$ & 0.0039 \\
\hline Synaptotagmin IV/ $\beta$-actin & $0.270 \pm 0.0064$ & $0.385 \pm 0.154$ & $30 \% \downarrow$ & NS \\
\hline$\beta$-Actin & $10.2 \pm 1.78$ & $10.4 \pm 1.03$ & $2 \% \downarrow$ & NS \\
\hline
\end{tabular}

Two-tailed unpaired t-test.

NS, nonsignificant.

$\uparrow$ Increases.

$\downarrow$ Decreases.

Table 5 Positive Associations between Olanzapine-Expressed Genes and Neuropsychiatric Disorders

\begin{tabular}{|c|c|c|c|c|c|c|c|}
\hline Gene & Schizophrenia & Mental retardation & Alcoholism & Depression & Alzheimer's & Bipolar & Autism \\
\hline Homer-linked oligophrenin-I & - & $\downarrow^{2}$ & - & - & - & - & - \\
\hline Homer I & Polymorphism ${ }^{4}$ & - & - & - & - & - & - \\
\hline Synaptotagmin IV & $\downarrow^{5}$ & - & - & - & - & - & - \\
\hline CART & - & - & Polymorphism9 & - & - & - & - \\
\hline Calbindin & $\downarrow^{10}$ & - & - & - & - & - & - \\
\hline NMDA3B & $\downarrow^{11}$ & - & - & - & - & - & - \\
\hline Reelin & $\downarrow$ Brain $^{13}$ & - & - & $\downarrow$ Brain $^{13}$ & - & $\downarrow$ Brain $^{13}$ & $\downarrow$ Brain and blood ${ }^{14}$ \\
\hline
\end{tabular}

I. Hashimoto et al (2003); 2. Govek et al (2004); 3. Tsuang et al (2005); 4. Norton et al (2003); 5. Ferguson et al (200 I); 6. Mirnics et al (200 I); 7. Muma et al (2003); 8. Stone et al (2004); 9. Jung et al (2004); I 0. Iritani et al (1999); I I. Lipsky and Goldman (2003); I2. Evans et al (2004); I 3. Fatemi et al (2000); Guidotti et al (2000); I4. Fatemi et al (2005b).

$\uparrow$ Increases.

$\downarrow$ Decreases.

Levels of synaptotagmin IV have been reported to be significantly decreased in schizophrenic subjects (Ferguson et al, 2001). Interestingly, we found that olanzapine significantly reduced synaptotagmin IV mRNA levels in rats treated with this agent (Tables 1,3 ) as well as a $20 \%$ decrease in protein levels (Table 4), questioning the cause for change in the same protein purported to be due to schizophrenic pathology.

\section{Olanzapine Effects on Synaptic Plasticity}

Several lines of evidence show that glutamatergic hypofunction plays a role in pathology of schizophrenia (Javitt, 2004). Thus, improving the glutamate neurotransmission may help in treatment of some of the deficits present in schizophrenia. Olanzapine clearly affects several genes that modulate glutamate neurotransmission, for example, homer 1, NMDA3B, GRIP, Reelin, and RGS2. One of the important genes upregulated by olanzapine is Reln, which helps in normal lamination of the brain during embryogenesis and affects synaptic plasticity in adulthood (Beffert et al, 2005; Fatemi, 2005). Reelin deficiency has been shown to be present in schizophrenia (Fatemi et al, 2000; Guidotti et al, 2000). Recent reports show that Reelin receptor ApoER2 interacts with, and alters the conformation of NMDA receptors NR2A and NR2B (Beffert et al, 2005). Additionally, Reelin induces tyrosine phosphorylation of NR2A and NR2B receptors in hippocampal tissue (Beffert et al, 2005), thus modulating NMDA receptor activity and synaptic plasticity in the hippocampus. As such, olanzapine helps to improve cognition/memory processing by upregulating Reelin expression, potentially via a complex interaction that may involve $N M D A 3 B$, Homer 1, RGS2, and GRIP. Supporting evidence for the potential role in olanzapine enhancing neuroplasticity was recently shown by Lieberman et al (2005) who demonstrated a cessation of brain grey matter loss in brains of patients with schizophrenia treated with olanzapine for 12 weeks and not in those 
treated for the same time period with haloperidol. Additionally, Wang and Deutch (2004) also showed that olanzapine prevented decreases in spine density of basilar dendrites on layers II, III, and IV of the PFC pyramidal neurons in rats lesioned with 6-hydroxydopamine. The propensity to affect glutamate neurotransmission is not restricted to olanzapine, since other atypical agents like clozapine, risperidone, and quetiapine are capable of affecting the same neurotransmitter system (Wang et al, 2000; Tarazi et al, 2003).

\section{Olanzapine Effects on Glucose Production}

Olanzapine affects glucose production via participation of several gene families involved in various metabolic pathways (Table 2). Olanzapine upregulates pyruvate kinase, an enzyme that catalyzes the formation of pyruvate and ATP from phosphoenolpyruvate and ADP. Pyruvate kinase polymorphisms have been discovered in subjects with schizophrenia (Stone et al, 2004) and Type II diabetes (Wang et al, 2002), and olanzapine increases the risk for diabetes in subjects with schizophrenia (Meyer and Nasrallah, 2003). Olanzapine also upregulates glycogen phosphorylase, a key enzyme in glycogen degradation, leading to removal of a terminal glucose residue from the nonreducing end of a glycogen chain providing more glucose for local brain energy expenditure. Indeed, glycogen phosphorylation is localized primarily to astrocytes in the brain alluding to a direct effect by olanzapine on glial cells (Pfeiffer-Guglielmi et al, 2003). Antipsychotics can affect brain concentrations of glycogen phosphorylases (Ktenas et al, 1978; Iriye and Simmonds, 1971a,b); however, the majority of typical antipsychotics reduce the levels of glycogen phosphorylase while antidepressants and olanzapine increase the activity of this enzyme (Iriye and Simmonds, 1971a). Olanzapine also increases insulin 2 expression, which may be in response to increased glucose production or potentially due to other triggers. By the same token, olanzapine can also reduce the concentration of sucrase-isomaltase to conserve glucose in disaccharide forms.

In summary, chronic administration of olanzapine to rats caused significant alterations in gene expression in 69 genes involved in signal transduction, cell communication, energy and metabolism, transport, immune response, cell growth, and nucleic acid metabolism. Specifically, olanzapine appears to enhance glutamate neurotransmission, modulate synaptic plasticity, and increase energy production via glycolytic pathways in rat frontal cortex. Future studies should correlate expression of genes following exposure to antipsychotic agents and those genes involved in pathology of psychiatric disorders in order to gain insights into the etiology and treatment of these disorders.

\section{ACKNOWLEDGEMENTS}

We appreciate the grant support provided by Stanley Medical Research Institute (SHF), the gift of olanzapine by Eli Lilly and Company, and the secretarial assistance by Ms L Iversen. Some of the data published in this manuscript were presented at International Congress of Schizophrenia, held at Savannah, Georgia and the Pharmacogenomics in Psychiatry Meeting at the Zucker Hillside Hospital in Glen Oaks, NY, in April of 2005.

\section{REFERENCES}

Angelucci F, Aloe L, Iannitelli A, Gruber SH, Mathe AA (2005). Effect of chronic olanzapine treatment on nerve growth factor and brain-derived neurotrophic factor in the rat brain. Eur Neuropsychopharmacol 15: 311-317.

Beffert U, Weeber EJ, Durudas A, Qiu S, Masiulis I, Sweatt JD et al (2005). Modulation of synaptic plasticity and memory by reelin involves differential splicing of the lipoprotein receptor apoer2. Neuron 47: 567-579.

Bymaster FP, Rasmussen K, Calligaro DO, Nelson DL, DeLapp NW, Wong DT et al (1997). In vitro and in vivo biochemistry of olanzapine: a novel, atypical antipsychotic drug. J Clin Psychiatry 58(Suppl 10): 28-36.

Chen ML, Chen CH (2005). Microarray analysis of differentially expressed genes in rat frontal cortex under chronic risperidone treatment. Neuropsychopharmacology 30: 268-277.

Chong VZ, Costain W, Marriott J, Sindwani S, Knauer DJ, Wang JF et al (2004). Differential display polymerase chain reaction reveals increased expression of striatal rat glia-derived nexin following chronic clozapine treatment. Pharmacogenomics $J$ 4: 379-387.

Chong VZ, Young LT, Mishra RK (2002). cDNA array reveals differential gene expression following chronic neuroleptic administration: implications of synapsin II in haloperidol treatment. J Neurochem 82: 1533-1539.

DeLisi LE, Shaw SH, Crow TJ, Shields G, Smith AB, Larach VW et al (2002). A genome wide scan for linkage to chromosomal regions in 382 sibling pairs with schizophrenia or schizoaffective disorder. Am J Psychiatry 159: 803-812.

Doublier S, Duyckaerts C, Seurin D, Binoux M (2000). Impaired brain development and hydrocephalus in a line of transgenic mice with liver-specific expression of human insulin-like growth factor binding protein-1. Growth Horm IGF Res 10: 267-274.

Elshatory Y, Brooks AI, Chattopadhyay S, Curran TM, Gupta P, Ramalingam $\mathrm{V}$ et al (2003). Early changes in gene expression in two models of Batten disease. FEBS Lett 538: 207-212.

Evans SJ, Choudary PV, Neal CR, Li JZ, Vawter MP, Tomita H et al (2004). Dysregulation of the fibroblast growth factor system in major depression. Proc Natl Acad Sci USA 101: 15506-15511.

Fatemi SH (2005). Reelin glycoprotein: structure, biology and roles in health and disease. Molecular Psychiatry 10: 251-257.

Fatemi SH, Earle JA, McMenomy T (2000). Reduction in Reelin immunoreactivity in hippocampus of subjects with schizophrenia, bipolar disorder and major depression. Mol Psychiatry 5: 654-663.

Fatemi SH, Kroll JL, Stary JM (2001b). Altered levels of Reelin and its isoforms in schizophrenia and mood disorders. Neuroreport 12: 3209-3215.

Fatemi SH, Meltzer HY (2000). Binding of olanzapine to serotonin receptors. In: Tran PV, Bymaster FP, Tye N, Herrera JM, Breier A, Tollefson GD (eds). Olanzapine (Zyprexa): A Novel Antipsychotic. Lippincott, Williams and Wilkins: Baltimore, MD. pp 25-30.

Fatemi SH, Pearce DA, Brooks AI, Sidwell RW (2005c). Prenatal viral infection in mouse causes differential expression of genes in brains of mouse progeny: a potential animal model for schizophrenia and autism. Synapse 57: 91-99.

Fatemi SH, Snow AV, Stary JM, Araghi-Niknam M, Reutiman TJ, Lee $S$ et al (2005b). Reelin signaling is impaired in autism. Biol Psychiatry 57: 777-787. 
Fatemi SH, Stary JM, Egan EA (2002). Reduced blood levels of Reelin as a vulnerability factor in pathophysiology of autistic disorder. Cell Mol Neurobiol 22: 139-152.

Fatemi SH, Stary JM, Earle JA, Araghi-Niknam M, Eagan E (2005a). GABAergic dysfunction in schizophrenia and mood disorders as reflected by decreased levels of glutamic acid decarboxylase 65 and $67 \mathrm{kDa}$ and Reelin proteins in cerebellum. Schizophr Res 72: 109-122.

Fatemi SH, Stary JM, Halt AR, Realmuto GR (2001a). Dysregulation of Reelin and bcl-2 proteins in autistic cerebellum. Autism Dev Disord 31: 529-535.

Ferguson GD, Vician L, Herschman HR (2001). Synaptotagmin IV: biochemistry, genetics, behavior, and possible links to human psychiatric disease. Mol Neurobiol 23: 173-185.

Govek EE, Newey SE, Akerman CJ, Cross JR, Van der Veken L, Van Aelst L (2004). The X-linked mental retardation protein oligophrenin-1 is required for dendritic spine morphogenesis. Nat Neurosci 7: 364-372.

Grafstein-Dunn E, Young KH, Cockett MI, Khawaja XZ (2001). Regional distribution of regulators of G-protein signaling (RGS) $1,2,13,14,16$, and GAIP messenger ribonucleic acids by in situ hybridization in rat brain. Brain Res Mol Brain Res 88: 113-123.

Guidotti A, Auta J, Davis JM, Di-Giorgi-Gerevini V, Dwivedi Y, Grayson DR et al (2000). Decrease in reelin and glutamic acid decarboxylase67 (GAD67) expression in schizophrenia and bipolar disorder: a postmortem brain study. Arch Gen Psychiatry 57: 1061-1069.

Gunnell D, Holly JM (2004). Insulin-like growth factors, insulin resistance and schizophrenia. Br J Psychiatry 185: 353-354.

Hashimoto K, Shimizu E, Komatsu N, Nakazato M, Okamura N, Watanabe $\mathrm{H}$ et al (2003). Increased levels of serum basic fibroblast growth factor in schizophrenia. Psychiatry Res 120: 211-218.

Hoffman DC, Donovan H (1995). Catalepsy as a rodent model for detecting antipsychotic drugs with extrapyramidal side effects liability. Psychopharmacology 120: 128-133.

Hubbell E, Liu W, Mei R (2002). Robust estimators for expression analysis. Bioinformatics 12: 1585-1592.

Hunter RG, Kuhar MJ (2003). CART peptides as targets for CNS drug development. Curr Drug Targets CNS Neurol Disord 2: 201-205.

Iritani S, Kuroki N, Ikeda K, Kazamatsuri H (1999). Calbindin immunoreactivity in the hippocampal formation and neocortex of schizophrenics. Prog Neuropsychopharmacol Biol Psychiatry 23: $409-421$.

Iriye TT, Simmonds FA (1971a). Effect of tranquilizers and antidepressants on glycogen phosphorylase of rat brain. Biochem Pharmacol 20: 1889-1900.

Iriye TT, Simmonds FA (1971b). Possible involvement of glycogen phosphorylase of brain in the affective states. Int Pharmacopsychiatry 6: 98-110.

Irizarry RA, Hobbs B, Collin F, Beazer-Barclay YD, Antonellis KJ, Scherf $U$ et al (2003). Exploration, normalization, and summaries of high density oligonucleotide array probe level data. Biostatistics 4: 249-264.

Javitt DC (2004). Glutamate as a therapeutic target in psychiatric disorders. Mol Psychiatry 9: 984-997.

Jung SK, Hong MS, Suh GJ, Jin SY, Lee HJ, Kim BS et al (2004). Association between polymorphism in intron 1 of cocaine- and amphetamine-regulated transcript gene with alcoholism, but not with bipolar disorder and schizophrenia in Korean population. Neurosci Lett 365: 54-57.

Kehrl JH, Sinnarajah S (2002). RGS2: a multifunctional regulator of G-protein signaling. Int J Biochem Cell Biol 34: 432-438.

Kontkanen O, Toronen P, Lakso M, Wong G, Castren E (2002). Antipsychotic drug treatment induces differential gene expression in the rat cortex. J Neurochem 83: 1043-1053.

Ktenas TB, Sotiroudis TG, Oikonomakos NG, Evangelopoulos AE (1978). Effect of phenothiazines on the activity of glycogen phosphorylase b. FEBS Lett 88: 313-316.
Kusumi I, Takahashi Y, Suzuki K, Kameda K, Koyama T (2000). Differential effects of subchronic treatments with atypical antipsychotic drugs on dopamine D2 and serotonin 5-HT2A receptors in the rat brain. J Neural Transmission 107: 295-302.

Lieberman JA, Tollefson GD, Charles C, Zipursky R, Sharma T, Kahn RS et al, HGDH Study Group (2005). Antipsychotic drug effects on brain morphology in first-episode psychosis. Arch Gen Psychiatry 62: 361-370.

Lipsky RH, Goldman D (2003). Genomics and variation of ionotropic glutamate receptors. Ann NY Acad Sci 1003: 22-35.

MacDonald ML, Eaton ME, Dudman JT, Konradi C (2005). Antipsychotic drugs elevate mRNA levels of presynaptic proteins in the frontal cortex of the rat. Biol Psych 57: 1041-1051.

Meyer JM, Nasrallah HS (eds) (2003). Medical Illness and Schizophrenia. American Psychiatric Publications, Inc.: Washington, DC.

Mirnics K, Middleton FA, Marquez A, Lewis DA, Levitt P (2000). Molecular characterization of schizophrenia viewed by microarray analysis of gene expression in prefrontal cortex. Neuron 28: 53-67.

Mirnics K, Middleton FA, Stanwood GD, Lewis DA, Levitt P (2001). Disease-specific changes in regulator of G-protein signaling 4 (RGS4) expression in schizophrenia. Mol Psych 6: $293-301$.

Muma NA, Mariyappa R, Williams K, Lee JM (2003). Differences in regional and subcellular localization of $\mathrm{G}(\mathrm{q} / 11)$ and RGS4 protein levels in Alzheimer's disease: correlation with muscarinic M1 receptor binding parameters. Synapse 47: 58-65.

Norton N, Williams HJ, Williams NM, Spurlock G, Zammit S, Jones $\mathrm{G}$ et al (2003). Mutation screening of the Homer gene family and association analysis in schizophrenia. Am J Med Genet B Neuropsychiatr Genet 120: 18-21.

Ovalle S, Zamanillo D, Andreu F, Farre AJ, Guitart X (2001). Fibroblast growth factor-2 is selectively modulated in the rat brain by E-5842, a preferential sigma-1 receptor ligand and putative atypical antipsychotic. Eur J Neurosci 13: 909-915.

Pfeiffer-Guglielmi B, Fleckenstein B, Jung G, Hamprecht B (2003). Immunocytochemical localization of glycogen phosphorylase isozymes in rat nervous tissues by using isozyme-specific antibodies. J Neurochem 85: 73-81.

Polese D, de Serpis AA, Ambesi-Impiombato A, Muscettola G, de Bartolomeis A (2002). Homer la gene expression modulation by antipsychotic drugs: involvement of the glutamate metabotropic system and effects of D-cycloserine. Neuropsychopharmacology 27: 906-913.

Riva MA, Molteni R, Tascedda F, Massironi A, Racagni G (1999). Selective modulation of fibroblast growth factor-2 expression in the rat brain by the atypical antipsychotic clozapine. Neuropharmacology 38: 1075-1082.

Schägger H, von Jagow G (1987). Tricine-sodium dodecyl sulfatepolyacrylamide gel electrophoresis for the separation of proteins in the range from 1-100 kDa. Anal Biochem 166: 368-379.

Siderovski DP, Heximer SP, Forsdyke DR (1994). A human gene encoding a putative basic helix-loop-helix phosphoprotein whose mRNA increases rapidly in cycloheximide-treated blood mononuclear cells. DNA Cell Biol 13: 125-147.

Stone WS, Faraone SV, Su J, Tarbox SI, Van Eerdewegh P, Tsuang MT (2004). Evidence for linkage between regulatory enzymes in glycolysis and schizophrenia in a multiplex sample. Am J Med Genet B Neuropsychiatr Genet 127: 5-10.

Tarazi FI, Baldessarini RJ, Kula NS, Zhang K (2003). Long-term effects of olanzapine, risperidone, and quetiapine on ionotropic glutamate receptor types: implications for antipsychotic drug treatment. J Pharmacol Exp Ther 306: 1145-1151.

Taymans JM, Leysen JE, Langlois X (2003). Striatal gene expression of RGS2 and RGS4 is specifically mediated by dopamine D1 and D2 receptors: clues for RGS2 and RGS4 functions. J Neurochem 84: 1118-1127. 
Thomas EA, George RC, Danielson PE, Nelson PA, Warren AJ, Lo $\mathrm{D}$ et al (2003). Antipsychotic drug treatment alters expression of mRNAs encoding lipid metabolism-related proteins. Mol Psychiatry 8: 983-993, 950.

Timmerman W, Heijmen M, Westerink BH, Bruggeman R, den Boer JA (1999). Effects of acute and chronic administration of olanzapine in comparison to clozapine and haloperidol on extracellular recordings of substantia nigra reticulata neurons in the rat brain. Psychopharmacology (Berlin) 144: 286-294.

Toriumi C, Imai K (2003). Altered expression of insulins I and II and their mRNAs in the islets of Langerhans in dexamethasoneinduced diabetic rats. Biomed Chromatogr 17: 26-32.

Tsuang MT, Nossova N, Yager T, Tsuang MM, Guo SC, Shyu $\mathrm{KG}$ et al (2005). Assessing the validity of blood-based gene expression profiles for the classification of schizophrenia and bipolar disorder: a preliminary report. Am J Med Genet B Neuropsychiatr Genet 133: 1-5.

Turek FW, Joshu C, Kohsaka A, Lin E, Ivanova G, McDearmon E et al (2005). Obesity and metabolic syndrome in circadian clock mutant mice. Science 308: 1043-1045.
VanderVorst A (2004). Homer: expression in chick ciliary ganglia. Saltman Q 1: 20-22.

Wang H, Chu W, Das SK, Ren Q, Hasstedt SJ, Elbein SC (2002). Liver pyruvate kinase polymorphisms are associated with type 2 diabetes in northern European Caucasians. Diabetes 51: 2861-2865.

Wang HD, Deutch AY (2004). Olanzapine reverses dopamine depletion-induced dendritic spine loss in prefrontal cortical pyramidal neurons. 34th Annual Meeting of Society for Neuroscience, San Diego, CA.

Wang RY, Liang X, Jardemark KE, Arvanov V (2000). Facilitation of NMDA transmission by olanzapine. In: Tran PV, Bymaster FP, Tye N, Herrera JM, Breier A, Tollefson GD (eds). Olanzapine (Zyprexa): A Novel Antipsychotic. Lippincott, Williams and Wilkins: Baltimore, MD. pp 114-136.

Wu Z, Irizarry R, Gentleman R, Murillo F, Spencer F (2004). A model based background adjustment for oligonucleotide expression arrays. Technical report, Johns Hopkins University. Department of Biostatistics working papers, Baltimore, MD.

Supplementary Information accompanies the paper on Neuropsychopharmacology website (http://www.nature.com/npp). 